\title{
Partially hydrolysed, prebiotic supplemented whey formula for the prevention of allergic manifestations in high risk infants: a multicentre double-blind randomised controlled trial
}

\author{
Robert Boyle ${ }^{1 *}$, Nick Brown², Wen Chin Chiang ${ }^{3}$, Chua Mei Chien³ ${ }^{3}$ Michael Gold ${ }^{4}$ onathas 'gurihane',

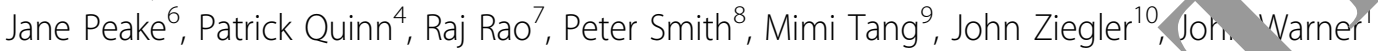

From Food Allergy and Anaphylaxis Meeting 2014

Dublin, Ireland. 9-11 October 2014

\section{Background}

We have for the first time evaluated whether a partially hydrolysed whey based (pHF) formula combined with specific mixture of prebiotic oligosaccharides would reduce the risk of allergic manifestations (AM) in formula-fed infants at increased risk of allergy.

\section{Methods}

We recruited term, healthy newborn ifants $m: 10$ centres in Australia, Singapore, En fland and Ireland. They had at least one parent with lergic disease and were randomised to receive a $\mathrm{pHF}^{-}$hi ic formula (active; 432) or standard cow ilk formula (control; 431) for the first 26 weeks of life in $/$ arents decided to stop or supplement ior tfeecling < 18 weeks. 324 infants were followea f arrence of AM until 3-5 years (ISRCTN6519559;

Primary outco was cjmulative incidence of atopic dermatitis (AD) $u_{i}$ o/12 months in the key group of interest (KGI), which consisted of those infants that started Mula - 28 days of age (active 375; control 38 , econ and post-hoc outcomes are reported on ' su iscts randomised.

Resu is

In the KGI, AD developed in 93/324 (29\%) infants randomised to control and 84/293 (29\%) to active (OR 0.94 -

${ }^{1}$ Imperial College London, London, United Kingdom

Full list of author information is available at the end of the article
[95\%CI 0.6 1.35]). We found no difference in AM at 3-5

vars. The a âve group had lower serum cow's milk (CM) IgG $t 6$ months than the control $(\mathrm{p}<0.0001)$ and this dif"ren e was still observed at 3 years $(p=0.007)$. Higher c 1 gG1 levels at 6 months were significantly associated with development of specific IgE (CM, hen's egg) at 3 years $(p<0.05)$. We found no difference between groups in adverse events.

Post-hoc analyses were performed on infants who had not introduced solids $<18$ weeks $(n=312)$. In this subgroup, active formula was associated with reduced $A M$ at $3-5$ years $(n=144 ; p=0.0334)$ and lower levels of total-IgE and hen's egg $\operatorname{IgE}$ at 6 months $(n=239$, $\mathrm{p}=0.0092$ and $\mathrm{n}=244, \mathrm{p}=0.0061$ ) compared with control group.

\section{Conclusion}

Early feeding with a pHF-prebiotic formula was not associated with a reduced risk of $\mathrm{AD}$ at 12 months or $\mathrm{AM}$ at 3-5 years. The pHF-prebiotic formula use did show a persistent immune-modulatory effect and possibly a reduced occurrence of AM in infants who introduced solids according to guidelines ( $>18$ weeks).

\section{Authors' details}

${ }^{1}$ Imperial College London, London, United Kingdom. ${ }^{2}$ Salisbury Healthcare NHS Trust, Salisbury, United Kingdom. ${ }^{3} \mathrm{KK}$ Women's and Children's Hospital, Singapore, Singapore. 'Women's and Children's Hospital, Adelaide, Australia. ${ }^{5}$ University College, Cork, Ireland. ${ }^{6}$ Royal Children's Hospital, Brisbane,

Australia. ${ }^{7}$ Poole Hospital NHS Trust, Poole, United Kingdom. ${ }^{8}$ Gold Coast 
Hospital, Gold Coast, Australia. ${ }^{9}$ Murdoch Children's Research Institute, Melbourne, Australia. ${ }^{10}$ Sydney Children's Hospital, Sydney, Australia.

Published: 30 March 2015

doi:10.1186/2045-7022-5-S3-P30

Cite this article as: Boyle et al: Partially hydrolysed, prebiotic supplemented whey formula for the prevention of allergic manifestations in high risk infants: a multicentre double-blind randomised controlled trial. Clinical and Translational Allergy 2015 5(Suppl 3):P30
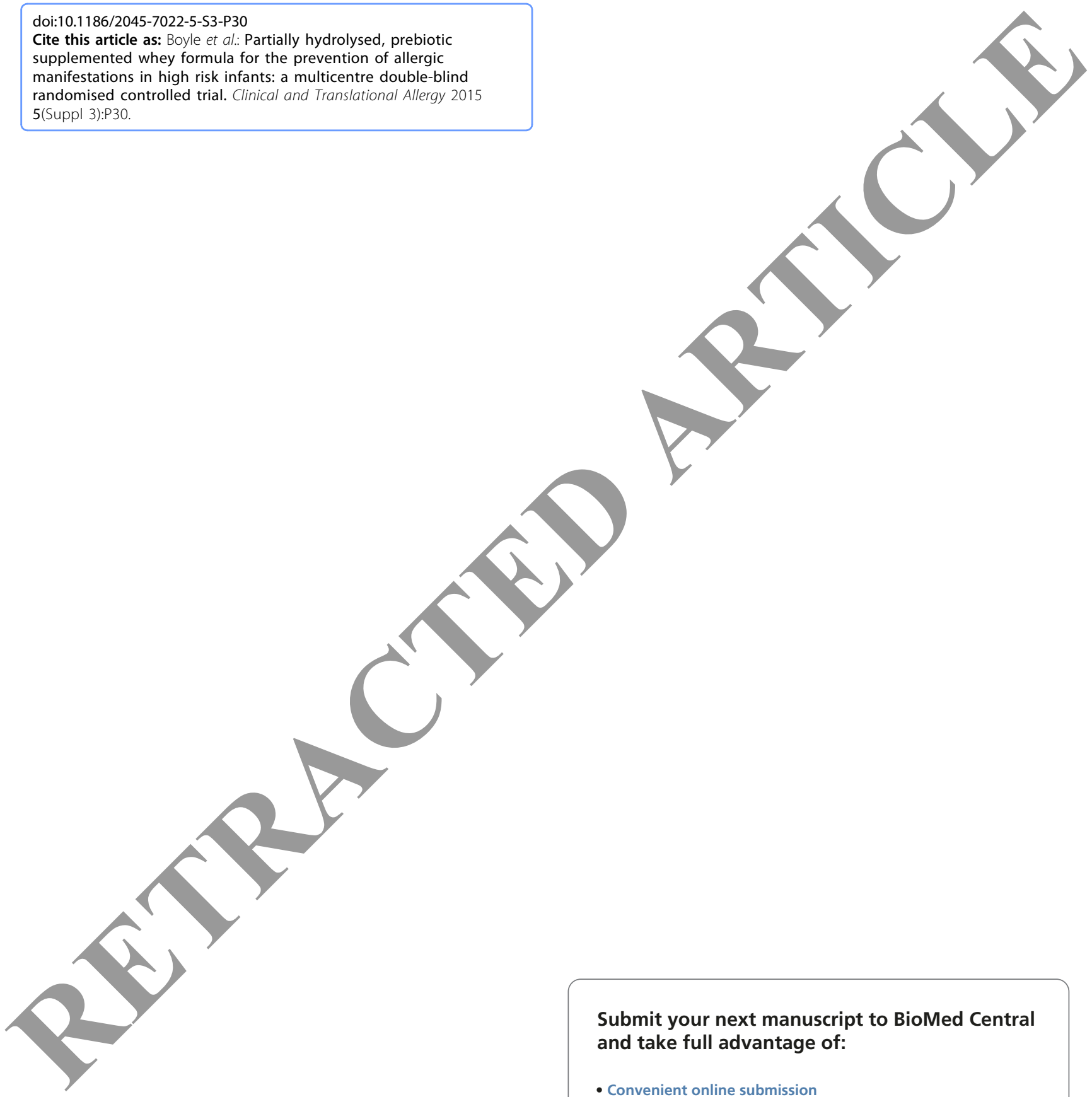

Submit your next manuscript to BioMed Central and take full advantage of:

- Convenient online submission

- Thorough peer review

- No space constraints or color figure charges

- Immediate publication on acceptance

- Inclusion in PubMed, CAS, Scopus and Google Scholar

- Research which is freely available for redistribution

Submit your manuscript at www.biomedcentral.com/submit 